\title{
Cigarette smoke alters the invariant natural killer $T$ cell function and may inhibit anti-tumor responses
}

\author{
Andrew E. Hogan ${ }^{a, *}$, Michelle A. Corrigan ${ }^{a}$, Vincent O'Reilly ${ }^{b}$, \\ Gadintshware Gaoatswe ${ }^{a}$, Jean O'Connell ${ }^{a}$, Derek G. Doherty ${ }^{b}$, \\ Lydia Lynch $^{a, c}$, Donal O'Shea ${ }^{a, d}$
}

a Obesity Immunology Group, Education and Research Centre, St Vincents University Hospital, UCD, Dublin 4, Ireland

${ }^{\mathrm{b}}$ Human Immunology Group, Institute of Molecular Medicine, St James Hospital, TCD, Dublin 8, Ireland

${ }^{c}$ Hematology and Oncology Beth Israel Deaconess Medical Centre, Harvard Medical School, Boston, USA

'St Columncille's Hospital, Loughlinstown, Dublin, Ireland

Received 4 October 2010; accepted with revision 21 January 2011

Available online 2 February 2011

\section{KEYWORDS \\ iNKT cells; \\ Cigarette smoke; \\ Anti-tumor responses}

\begin{abstract}
Invariant natural killer T (iNKT) cells are a minor subset of human T cells which express the invariant $\mathrm{T}$ cell receptor $\mathrm{V}_{\alpha 2} 24 \mathrm{~J} \alpha 18$ and recognize glycolipids presented on CD1d. Invariant NKT cells are important immune regulators and can initiate anti-tumor responses through early potent cytokine production. Studies show that iNKT cells are defective in certain cancers. Cigarette smoke contains many carcinogens and is implicated directly and indirectly in many cancers. We investigated the effects of cigarette smoke on the circulating iNKT cell number and function. We found that the iNKT cell frequency is significantly reduced in cigarette smoking subjects. Invariant NKT cells exposed to cigarette smoke extract (CSE) showed significant defects in cytokine production and the ability to kill target cells. CSE inhibits the upregulation of CD107 but not CD69 or CD56 on iNKT cells. These findings suggest that CSE has a specific effect on iNKT cell anti-tumor responses, which may contribute to the role of smoking in the development of cancer.

(c) 2011 Elsevier Inc. All rights reserved.
\end{abstract}

Abbreviations: $\alpha$ GalCer, $\alpha$-Galactosylceramide, CSE, Cigarette smoke extract, iNKT, Invariant natural killer T cell, PBMC, Peripheral blood mononuclear cells

* Corresponding author at: Obesity Immunology Group, Education and Research Centre, University College Dublin, St. Vincent's University Hospital Dublin 4, Ireland.

E-mail address: Andrew.Hogan.3@ucd.ie (A.E. Hogan).

\section{Introduction}

Smoking is the main cause of preventable morbidity and mortality in the world [1]. Carcinogens from cigarette smoke can lead directly to lung cancer [2] and are implicated in several other malignancies such as bladder, cervix, stomach, liver and kidney [3]. In addition to the increased cancer risk, smokers have increased susceptibility to infections [4] and a marked increase in autoimmune disorders such as rheumatoid arthritis [5]. 
Studies have shown that immunocompromised animals have an increased incidence of cancer [6]. Circulating natural killer (NK) cell number and anti-tumor activity are reduced in smokers compared to non-smokers $[7,8]$. We have previously demonstrated that cigarette smoke extract (CSE) reduces the NK cell function in vitro in a dose-dependent manner [9]. These studies suggest that cigarette smoke alters the host immunity, enabling tumor cells and pathogens to evade immune responses and increasing susceptibility to autoimmune conditions.

Invariant natural killer T (iNKT) cells are a rare subset of human innate $T$ cells defined by their expression of the invariant $\mathrm{T}$ cell receptor (TCR) $\mathrm{V}_{\alpha 2} 24 \mathrm{~J} \alpha 18$ and NK-like surface molecules [10]. The invariant TCR recognizes glycolipid antigen such as the marine sponge-derived antigen $\alpha$ Galactosylceramide $(\alpha$ GalCer) $[11,12]$. Invariant NKT cells are potent immunomodulatory cytokine secreting cells, capable of simultaneously producing IFN- $\gamma$ and IL-4 when stimulated $[13,14]$. Invariant NKT cells respond rapidly to antigen $(\mathrm{Ag})$ or infection $(<2 \mathrm{~h})$ and can activate other cells of the innate and adaptive immune systems including NK cells [15]. Invariant NKT cells are implicated in the prevention of tumor growth and the eradication of existing tumors in mice $[16,17]$. In humans the number of circulating and tissue-resident iNKT cells are reduced in cancer [18-20]. Currently iNKT cells are the basis of numerous phase I and II oncology trials [21-24]. As well as their ability to rapidly produce immunomodulating cytokines, iNKT cells have been reported to lyse target tumor cells in vitro $[25,26]$.

The objective of this study was to investigate if cigarette smoke affects the function of iNKT cells. We investigated the levels of circulating iNKT cells in a cohort of healthy subjects who smoke 20 cigarettes daily compared to age-matched non-smoking individuals. We also investigated both the iNKT cell production of immune modulating cytokines and their ability to efficiently lyse tumor cells before and after exposure to CSE.

\section{Materials and methods}

\subsection{Ethics statement}

The ethics committee at St. Vincent's University Hospital, Dublin granted approval for all aspects of this study. Blood samples were obtained with informed written consent from healthy individuals who smoked 20 cigarettes daily and agematched controls.

\subsection{Preparation of PBMC cells}

$100 \mathrm{mls}$ of venous blood was collected in heparinized collection tubes. PBMCs were isolated by density centrifugation on Lymphoprep (Nycomed, Norway) at $400 \mathrm{~g}$ for $25 \mathrm{~min}$. Cells were washed twice and cell pellets were resuspended in $1 \mathrm{ml}$ of RPMI 1640 medium, and cell yields and viability were assessed by ethidium bromide/acridine orange staining. The cell suspension was adjusted to $100 \times 10^{6}$ cells $/ \mathrm{ml}$ in Miltenyi separation buffer (Miltenyi Biotech, UK).

\subsection{Generation of iNKT cell lines}

iNKT cells were isolated from PBMC cell suspensions by positive selection of anti-6b11 magnetic bead (Miltenyi Biotech, UK) labeled cells (as per manufacturer's instructions). The purified iNKT cell suspensions were stained with 6B11 PE and CD3 PE-CY5 monoclonal antibodies (mAb) (BD Biosciences, UK) for $30 \mathrm{~min}$, before washing. The cells were then sorted by high speed FACS for double positive cells $\left(6 \mathrm{~B} 11^{+} \mathrm{CD}^{+}\right)$using a MoFlo FACS (Dako Cytomation, USA). 1000 sorted cells were cultured per 96-round bottomed plate well in complete RPMI medium with 150,000 irradiated PBMC from 2 donors, $10 \mathrm{ng} / \mathrm{ml}$ of PHA (Sigma Aldrich, UK) and $250 \mathrm{U} / \mathrm{ml}$ of IL-2 (Immunotools, Germany). The PHA was diluted out over $48 \mathrm{~h}$ using a complete RPMI with $250 \mathrm{U} / \mathrm{ml}$ of IL-2. Media was replenished every 7-10 days and wells divided when required.

\subsection{Flow cytometric staining and analysis}

Cells were stained with optimal amounts of the previously titrated mAbs CD3, CD4, CD8, 6B11, CD56, CD69, CD107 and relevant isotype controls (BD Biosciences, UK) and incubated at $4{ }^{\circ} \mathrm{C}$ for $30 \mathrm{~min}$. Cells were washed twice in $\mathrm{pbs} / \mathrm{pba}$ and resuspended in 1\% PFA and acquired after a $10 \mathrm{~min}$ incubation at $4{ }^{\circ} \mathrm{C}$. Cells were analyzed using a FACSCalibur flow cytometer and CellQuest Pro software (BD Biosciences). Lymphocytes were gated ('lymphogate') by their density and granularity using forward scatter and side scatter parameters, which contained $95 \%$ of peripheral lymphocytes. All further analysis was performed on lymphocytes only. Thirty thousand lymphocyte events were acquired in each case. Frequencies were expressed as a percentage of lymphocytes (or iNKT cells where appropriate).

\subsection{Cigarette smoke extract}

A system for generating cigarette smoke was developed based upon a validated pump system described by Bernard and colleagues [27], with modifications described by Cawood et al. [28]. Smoke from four cigarettes was pumped through a $30 \mathrm{ml}$ RPMl culture medium. Ten puffs were pumped for each cigarette, each puff contributing $35 \mathrm{ml}$ of smoke, every $30 \mathrm{~s}$, resulting in approximately $75 \%$ of the cigarette being consumed, and the $350 \mathrm{ml}$ of smoke extract was generated per cigarette. Each milliliter of CSE contains $0.133(4 / 30)$ cigarette's worth of smoke-derived constituents. The resultant CSE was sterilized by filtering through a $0.2-\mu \mathrm{m}$ filter, $\mathrm{pH}$ adjusted to 7.4 , and then stored at $-20^{\circ} \mathrm{C}$. The cigarettes used were Marlboro Reds, Class A, rated as tar $10 \mathrm{mg}$, nicotine $0.8 \mathrm{mg}$, and carbon monoxide $10 \mathrm{mg}$. Bernhard's validated volumetric calculations are based on the assumption that a human generates $350 \mathrm{ml}$ smoke with each cigarette and has a blood volume of 6 liters. If that person smokes 20 cigarettes per day, then each $300 \mathrm{ml}$ $(6000 / 20)$ of blood contains the equivalent of one cigarette. Therefore, each milliliter of blood contains $0.0033(1 / 300)$ cigarette's worth of smoke-derived constituents. By this calculation, CSE can be considered to contain 40 times $(0.133 / 0.0033)$ the amount of smoke-derived constituents than would be expected in the blood of a smoker who smokes 
20 cigarettes per day. A 2.5\% (1/40) solution of CSE would equate to 20 cigarettes per day.

\subsection{Effect of CSE on iNKT phenotype}

iNKT cell lines were cultured with or without CSE, either alone or with CD1d transfected C1R cells at 1:1 ratio in the presence or absence of $100 \mathrm{ng} / \mathrm{ml}$ of $\alpha$ GalCer for $24 \mathrm{~h}$ in a 96 $\mathrm{U}$ bottom well plate at $37^{\circ} \mathrm{C}$. After $24 \mathrm{~h}$ cells were harvested and stained with the mAbs, CD3, CD4, CD8, 6B11, CD56, CD69 and CD107 and acquired by flow cytometry using a FACSCalibur and analyzed by Cell Quest

\subsection{Cytokine production assay}

iNKT cell lines with or without CSE, were cultured alone or co-cultured with CD1d transfected C1R cells at 1:1 ratio in the presence or absence of $100 \mathrm{ng} / \mathrm{ml}$ of $\alpha$ GalCer for $72 \mathrm{~h}$ in a 96-U bottom well plate at $37{ }^{\circ} \mathrm{C}$. After $24 \mathrm{~h} 125 \mu \mathrm{l}$ of culture supernatant was removed and assessed by ELISA (R\&D Systems, UK) and FlowCytomix (Bendermed Systems, UK) for cytokine secretion. At $72 \mathrm{~h}$ the remaining supernatant was assessed by ELISA.

\subsection{Cytotoxicity assay}

CD1d transfected Hela target cells loaded with $100 \mathrm{ng} / \mathrm{ml}$ of $\alpha$ GalCer were labeled with carboxyl fluorescein succinimidyl ester (CFSE) and then added to the iNKT cell populations at effector/target ratios 10:1. Cell co-cultures were incubated at $37{ }^{\circ} \mathrm{C}$ for $4 \mathrm{~h}$, in the absence or presence of CSE. Killing of CFSE-labeled target cells was measured by staining with 7aminoactinomycin D (7-AAD) immediately after incubation and by immediate analysis by flow cytometry (as per manufactucter's instructions for the flow cytometry-based Total Cytotoxicity \& Apoptosis Detection Kit, Immunochemistry, USA).

\section{Results}

\subsection{Enumeration of iNKT cells in cigarette smoking individuals}

The frequency of circulating iNKT cells in cigarette smoking subjects was assessed by flow cytometry using a combination of the mAbs 6B11 PE and CD3 Per-Cp and compared to age matched non-smoking cohort (Fig. 1). The frequency of iNKT cells was significantly lower in the smoking cohort (mean of $0.22 \%)$ compared to the non-smoking cohort $(0.33 \%)$ $(\mathrm{P}<0.05)$ the frequency of conventional $\mathrm{T}$ cells was unchanged between smokers and non-smokers (data not shown).

\subsection{Cell yields and viability}

There were no significant differences in cell viability after exposure to cigarette smoke extract as determined by EB/AO staining, in all cases viability exceeded $90 \%$ (data not shown).

\subsection{Generation of iNKT cell lines}

Five iNKT cell lines were generated and were assessed by flow cytometry to determine purity and phenotype of each (data not shown). Each line was $>99 \%$ positive for 6 B11, CD3 illustrating an enrichment $>200$-fold. The expression of the invariant TCR was also examined using the monoclonal antibody pairing of $V_{\alpha} 24$ and $V_{\beta} 11$, all cells were positive for $V_{\alpha} 24$ and for $V_{\beta} 11$. Of the 5 lines examined each had a mixed expression of CD4, CD8 and CD4-CD8-subsets (data not shown).

\subsection{Effect of CSE on iNKT phenotype}

Upon iNKT cell activation, the cell up regulates functional surface molecules. We aimed to investigate the effect of CSE

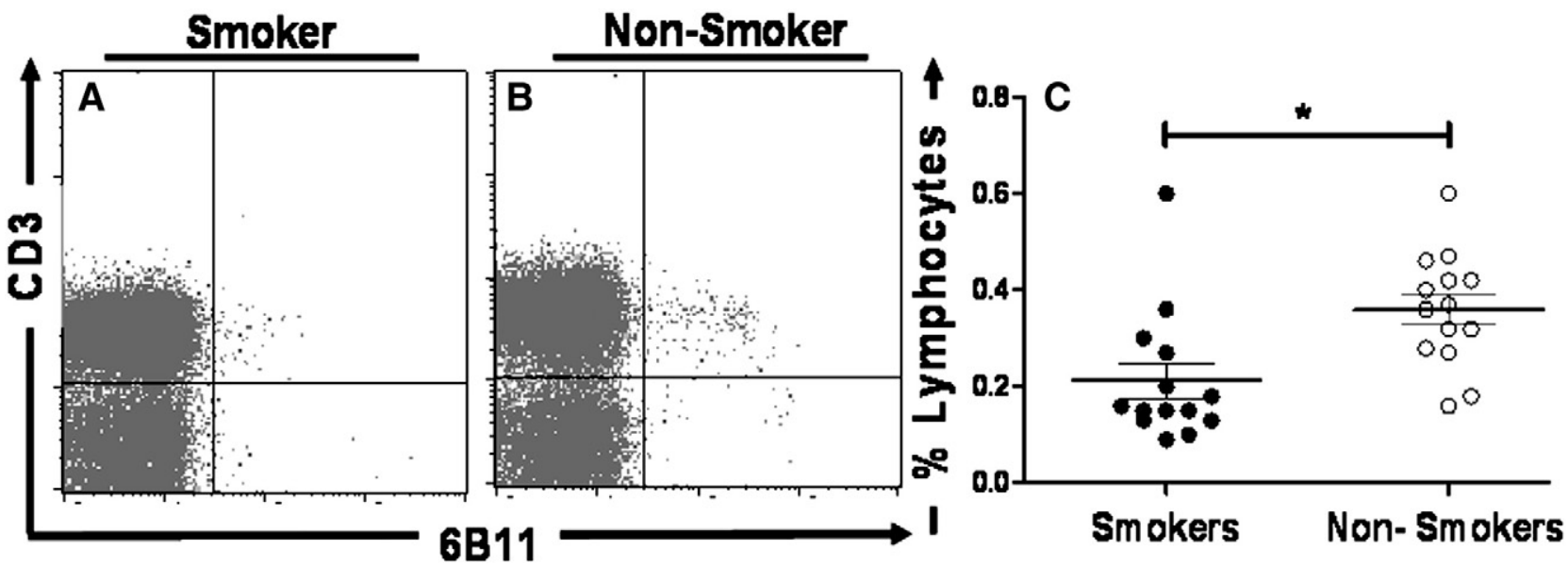

Figure 1 Enumeration of iNKT cells in cigarette smoking individuals. Representative flow cytometry dot plots showing peripheral blood mononuclear cells from (A) a cigarette smoking subject and (B) a non-smoking subject stained with the mAbs 6B11 PE and CD3 PE-Cy5. (C), scatter plot of iNKT frequencies in cigarette smoking cohort (black circles) and non-smoking cohort (unfilled circles), the black line denotes the mean frequency $(n=12) .{ }^{*}=p<0.05$. 
on the expression levels of iNKT activation markers (CD56, CD69) and the killing associated molecule CD107. Invariant NKT cells were co-cultured with CD1d-transfected C1R cells loaded or unloaded with $100 \mathrm{ng} / \mathrm{ml}$ of $\alpha$ GalCer for $24 \mathrm{~h}$ in the presence or absence of CSE. The expression of surface molecules was examined by flow cytometry. The expression of CD56, CD69 and CD107 was increased with the addition of $100 \mathrm{ng} / \mathrm{ml}$ of $\alpha \mathrm{GalCer}$. The presence of CSE only significantly inhibited the up regulation of CD107 ( $<<0.05$ ) (Fig. 2C). No significant difference was observed in the surface expression of CD56 or CD69 on the iNKT cells exposed to CSE and controls (Fig. 2A-B).

\subsection{Effect of CSE on iNKT cytokine production}

Invariant NKT cells were co-cultured with CD1d-transfected C1R cells loaded or unloaded with $100 \mathrm{ng} / \mathrm{ml}$ of $\alpha$ GalCer for 24 and $72 \mathrm{~h}$ in the presence or absence of CSE. After $24 \mathrm{~h}$ supernatants were assessed by Th1/Th2 flow cytomix assay and ELISA (Fig. 3A and B). There were significant increases in IFN- $\gamma$, TNF- $\alpha$, IL-4 and IL-5 ( $<<0.005)$ secretion by iNKT cells in the presence of $\alpha \mathrm{GalCer}$ compared to the iNKT and CD1dtransfected C1R cells in the absence of $\alpha$ GalCer (Fig. 3A and $B$ ). The addition of CSE resulted in the significant inhibition of IFN- $\gamma$ secretion as detected by flow cytomix assay $(p<0.005)$ and ELISA $(p<0.05)$ (Fig. 3A and B). CSE also inhibited the secretion of IL-4 by iNKT cells compared to the co-cultures in the presence of $\alpha$ GalCer when assessed by flow cytomix assay $(p<0.05)$ and ELISA $(p<0.05)$ (Fig. 3A and B). TNF- $\alpha$ and IL- 5 secretion by iNKT cells was examined by the flow cytomix assay and both were significantly increased in the presence of $\alpha \mathrm{GalCer}$. The addition of CSE resulted in a significant reduction in both TNF- $\alpha \quad(p<0.005)$ and IL-5 $(p<0.005)$ secretion after $24 \mathrm{~h}$ (Fig. 3A). After the $72 \mathrm{~h}$ culture, supernatants were assessed by ELISA for IFN- $\gamma$ and $\mathrm{IL}-4$ production. CSE had no effect on IFN- $\gamma$ levels, with comparable levels detected by ELISA between $\alpha \mathrm{GalCer}$ with and without CSE. Invariant NKT cells produced significantly more IL-4 in the presence of CSE $(p<0.05)$ than those cultured without CSE (Fig. 3B).

\subsection{Effect of CSE on iNKT cytotoxicity}

Invariant NKT cells were co-cultured with CFSE-labeled CD1d-transfected HeLa cells unloaded or loaded with $100 \mathrm{ng} / \mathrm{ml}$ of $\alpha \mathrm{GalCer}$ for $4 \mathrm{~h}$ in the presence or absence of CSE. After $4 \mathrm{~h}$ cell death was measured. Invariant NKT cells lysed $28 \%$ of HeLa target cells. The addition of CSE resulted in a reduction in the lysis to a mean of $17 \%$ (Fig. 4A). In the presence of $100 \mathrm{ng} / \mathrm{ml} \alpha \mathrm{GalCer}$, iNKT cells lysed $31 \%$ of HeLa target cells. The addition of CSE resulted in a reduction in the lysis to a mean of $21 \%$ (Fig. 4B), illustrating that CSE reduces iNKT cell cytotoxicity.

\section{Discussion}

Cigarette smoke has strong associations with several cancers and has previously been shown to inhibit important antitumor innate immune responses by NK cells $[3,9]$. Invariant NKT cells are important regulatory innate effector cells, with the potential to elicit specific immune responses through cytokine production $[15,29]$. This ability has highlighted iNKT cells as an attractive target for cancer immunotherapy [31]. The effect of tumor environment on iNKT cell frequency has been previously reported [18,19], however the effect of other environmental factors such as CSE has not been investigated. We aimed to determine if CSE altered the iNKT cell anti-tumor activity. Our study suggests the effect of CSE on iNKT cells is specific and reduces the population number and function.

We investigated the frequency of circulating iNKT cells in the peripheral blood of healthy cigarette-smoking subjects and found a significant reduction in the iNKT cell number compared to a non-smoking age-matched cohort (Fig. 1).

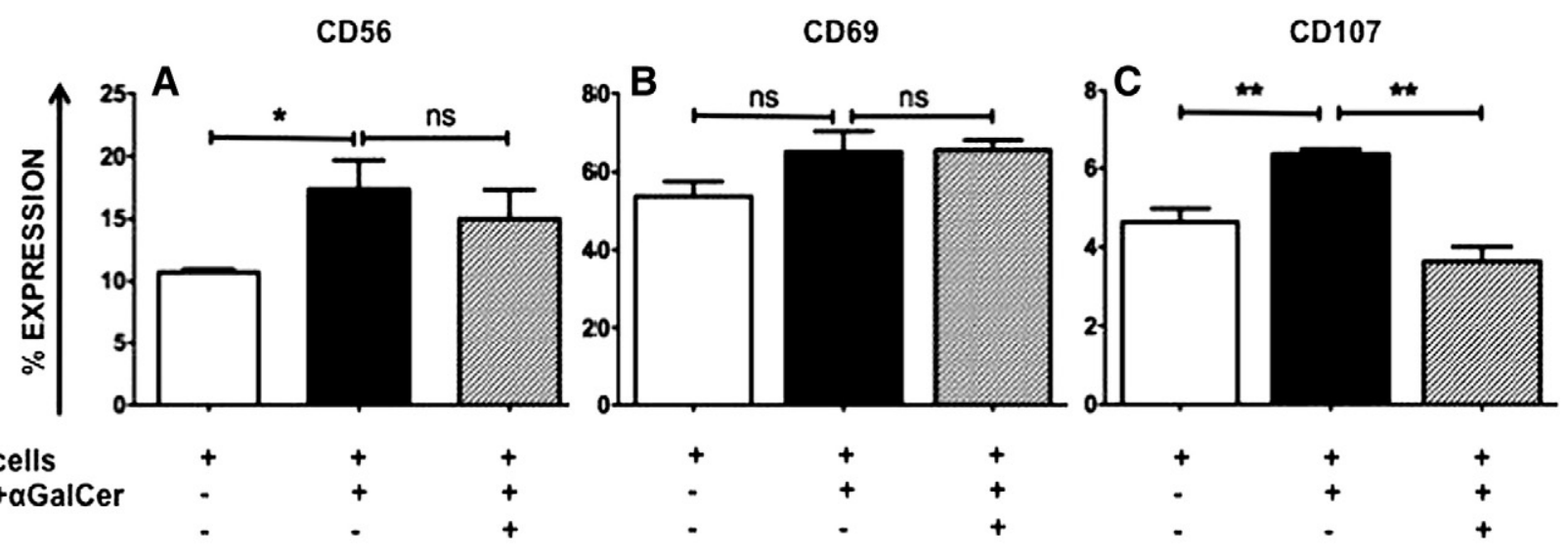

Figure 2 Effects of CSE inhibition on iNKT cell surface molecule expression. Bar graphs showing the surface expression of CD56 (A), CD69 (B) and CD107 (C) by iNKT cell lines. The iNKT cells were cultured with either CD1d transfected C1R cell in the absence or presence of $100 \mathrm{ng} / \mathrm{ml} \alpha \mathrm{GalCer}$, with or without CSE for $24 \mathrm{~h}$. Surface marker expression was examined by flow cytometry. The values are expressed percentage of iNKT cell expressing the molecule. Mean of 4 individual experiments. ${ }^{*}=p<0.05,{ }^{* *}=p 0.005, n s=n o n$ significant. 

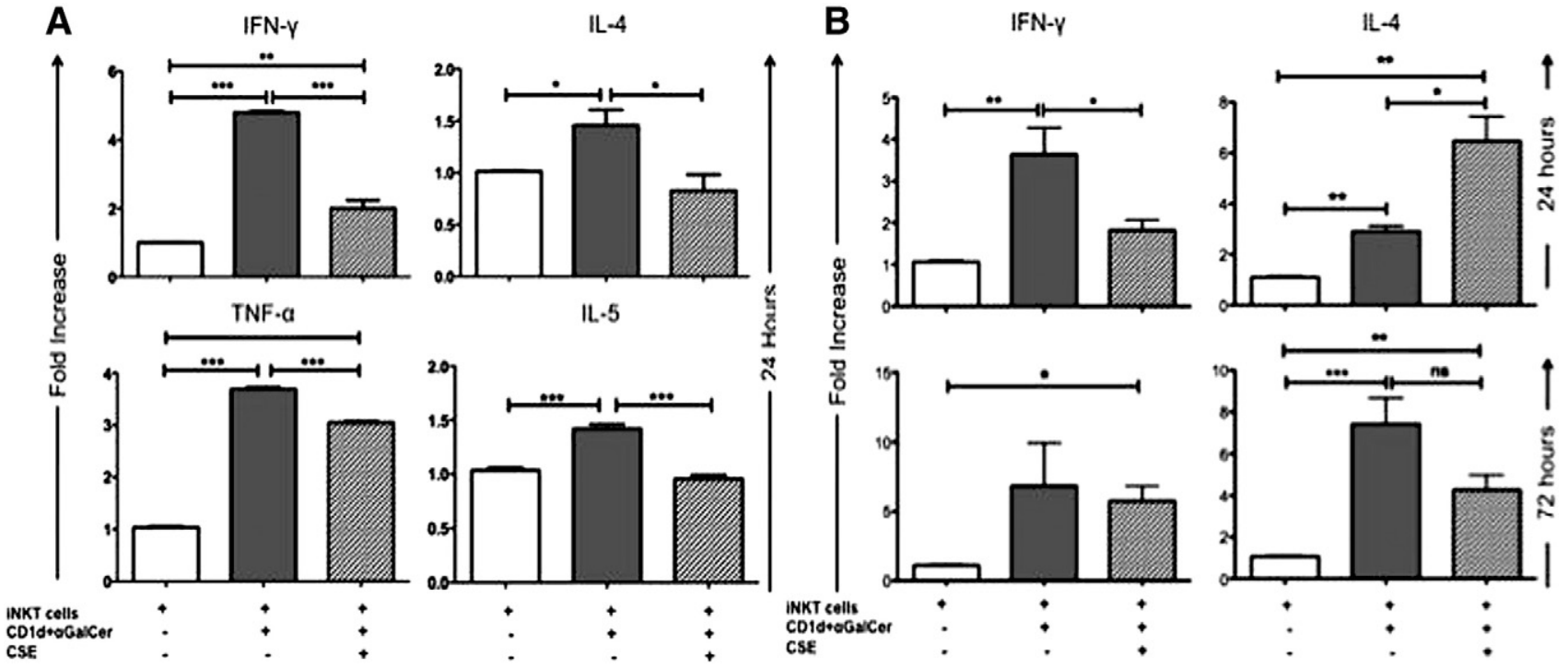

Figure 3 Investigation of CSE inhibition of iNKT cell derived cytokine secretion. Bar graphs showing IFN- $\gamma$, TNF- $\alpha$, IL-5 and IL-4 secretion by iNKT cell lines after $24 \mathrm{~h}$ measured by Flow cytometry multiplex assay (A). Bar graphs showing IFN- $\gamma$, and IL- 4 secretion by iNKT cell lines after 24 and $72 \mathrm{~h}$ measured by ELISA (B). The iNKT cells were cultured with either CD1d transfected C1R cell in the absence or presence of $100 \mathrm{ng} / \mathrm{ml} \alpha \mathrm{GalCer}$, with or without CSE for 24 or $72 \mathrm{~h}$. The values are expressed as fold increases in cytokine production over the iNKT cell cultured with CD1d transfected C1R cells. Graphs are representative of 5 individual experiments. ${ }^{*}=\mathrm{p}<0.05,{ }^{* *}=\mathrm{p}<0.005,{ }^{* * *}=\mathrm{p}<0.001$.

Tahir et al. previously showed that tumor environment depletes iNKT cell number [18]. Our findings add cigarette smoke as another environmental factor that leads to depletion of iNKT cells. The finding that iNKT cell numbers are reduced in cigarette-smoking subjects is novel. Reduced iNKT cell number has also been reported in conditions affected by smoking such as diabetes and head and neck squamous cell carcinoma (HNSCC). In HNSCC low levels of circulating iNKT cells predicted poor clinical outcomes in a group of 47 patients compared to individuals with intermediate or high levels of circulating iNKT cells [30].

In addition to a reduction in iNKT cell number our study also shows significant alteration in iNKT cell function. We examined iNKT cell cytokine secretion in response to $\alpha$ GalCer stimulation after $24 \mathrm{~h}$ in the absence or presence of CSE. As previously described, iNKT cells secrete significant amounts of IFN- $\gamma$ and IL-4 simultaneously when stimulated $[13,14]$. The addition of CSE resulted in a significant reduction in the production of both cytokines after $24 \mathrm{~h}$ (Fig. 3). We have previously reported that CSE inhibited intracellular IFN- $\gamma$ and increased IL-10 production by NK cells [9]. This would bias the immune system towards a $\mathrm{T}$ helper type 2 (Th2) response that does not have a significant antitumor activity. Cigarette smoke therefore appears to have multiple negative effects on the innate immune cells that are important in tumor surveillance and protection against infections.

CSE was also found to significantly inhibit the production of TNF- $\alpha$ and IL- 5 by iNKT cells (Fig. 3). Cytokine production was examined after $72 \mathrm{~h}$ to determine if the inhibitory effect observed persisted without the further addition of CSE. Invariant NKT cells stimulated with $\alpha$ GalCer produced comparable levels of IFN- $\gamma$ when co-cultured for $72 \mathrm{~h}$ in the absence or presence of CSE. The addition of CSE resulted in significantly increased levels of IL-4 after $72 \mathrm{~h}$ compared to iNKT cells incubated with CD1d-transfected C1R cells loaded with $\alpha$ GalCer (Fig. 3B). This finding demonstrates that iNKT cell cytokine production is inhibited in the presence of CSE and subsequently altered in a Th2 manner after $72 \mathrm{~h}$. The production of a Th2-biased cytokine milieu by iNKT cells has previously been reported in subjects with cancer [18].

The iNKT cell lines expressed the activation-associated surface molecules CD56 and CD69. These molecules were increased following stimulation with $\alpha \mathrm{GalCer}$. The addition of CSE to the cultures had no significant effect on the expression of either activation markers suggesting the iNKT cells were still activated by $\alpha$ GalCer (Fig. 2). Invariant NKT cells can lyse target cells by perforin CD107 [32,33]. We examined the expression of CD107 and observed that it was upregulated in the presence of $\alpha \mathrm{GalCer}$-loaded CD1d cells. This may be due to the specific lysing of CD1d-positive cells by iNKT cells as previously described [32,33]. With the addition of CSE, the upregulation of CD107 was inhibited (Fig. 2). We have shown that CSE also inhibited CD107 expression in NK cells without affecting other NK cell markers [9]. As a result of the inhibition of CD107upregulation we examined the effect of CSE on the iNKT cell cytotoxic ability. We demonstrated the significant inhibition of iNKT cell lysis of HeLa target cells both in the absence (Fig. 4C) and presence (Fig. 4D) of $\alpha$ GalCer (Fig. 4). This suggests further impairment of iNKT cell anti-tumor activity due to exposure to CSE (IFN- $\gamma$ production and tumor lysis). 

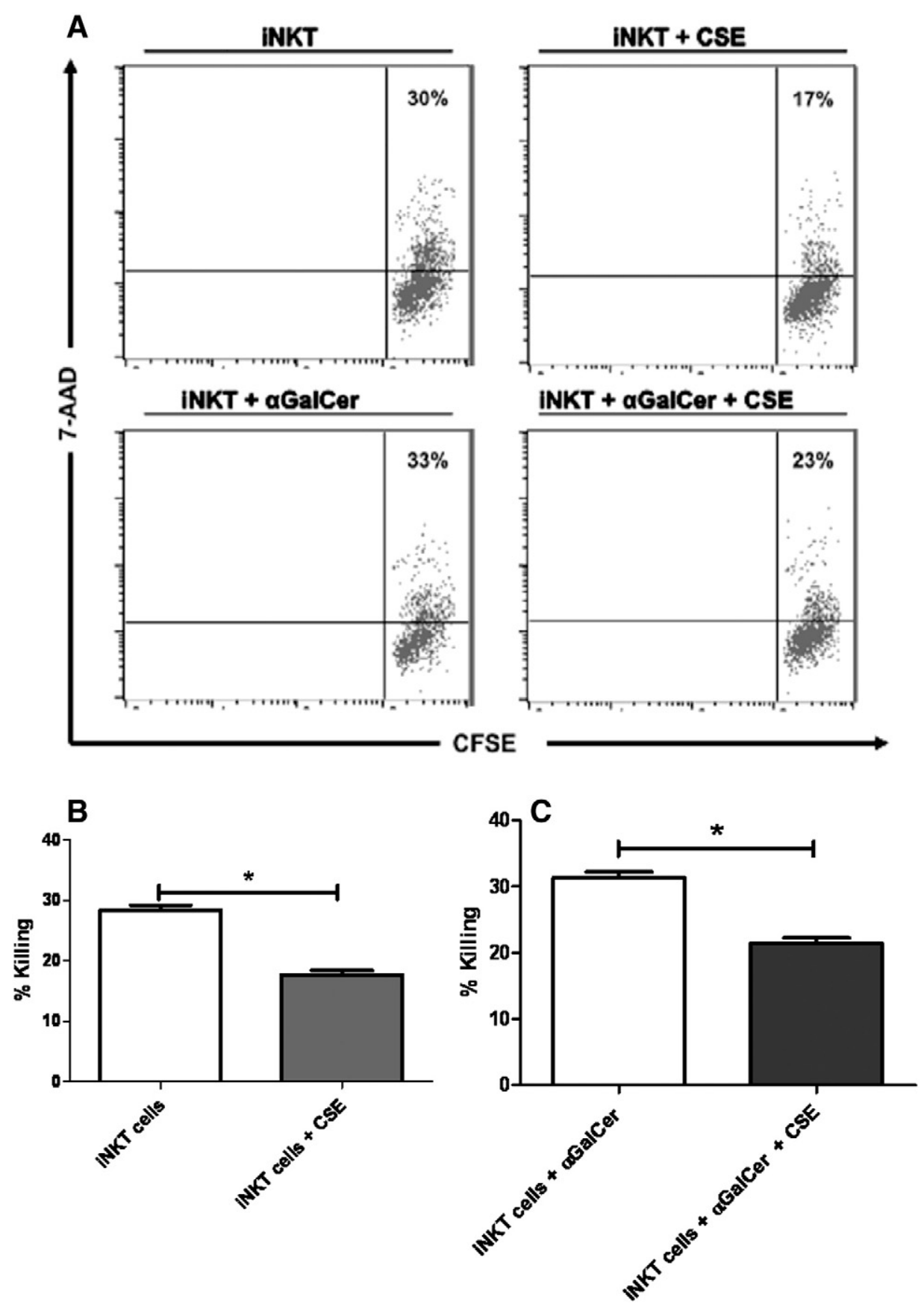

Figure 4 Investigation of CSE inhibition of iNKT cell cytotoxicity. Representative dot plots (A) showing the lysis of target cells by iNKT cells and (B and C) bar graphs displaying the mean percentage lysis. The iNKT cells were cultured with CFSE labeled CD1d transfected C1R cells in the absence or presence of $100 \mathrm{ng} / \mathrm{ml} \alpha \mathrm{GalCer}$, with or without CSE for $4 \mathrm{~h}$. Graphs are representative of 3 individual experiments. ${ }^{*}=\mathrm{p}<0.05$.

These findings demonstrate that cigarette smokers have a reduction in the number of circulating $\mathrm{iNKT}$ cells and that CSE directly alters iNKT cells anti-tumor activity.

\section{References}

[1] M. Ezzati, A.D. Lopez, Regional, disease specific patterns of smoking-attributable mortality in 2000, Tob. Control 13 (2004) 388-395.

[2] S.S. Hecht, Tobacco smoke carcinogens and lung cancer, J. Natl. Cancer Inst. 91 (1999) 1194-1210.
[3] M.R. Stampfli, G.P. Anderson, How cigarette smoke skews immune responses to promote infection, lung disease and cancer, Nat. Rev. Immunol. 9 (2009) 377-384.

[4] G.W. Chalmers, K.J. MacLeod, L. Thomson, S.A. Little, C. McSharry, N.C. Thomson, Smoking and airway inflammation in patients with mild asthma, Chest 120 (2001) 1917-1922.

[5] C. Carlens, M.P. Hergens, J. Grunewald, A. Ekbom, A. Eklund, C. Olgart Hoglund, J. Askling, Smoking, Use of Moist Snuff and Risk of Chronic Inflammatory Diseases, Am. J. Respir. Crit. Care Med. 181 (11) (2010) 1217-1222.

[6] S. Kim, K. lizuka, H.L. Aguila, I.L. Weissman, W.M. Yokoyama, In vivo natural killer cell activities revealed by natural killer 
cell-deficient mice, Proc. Natl. Acad. Sci. USA 97 (2000) 2731-2736.

[7] M. Ferson, A. Edwards, A. Lind, G.W. Milton, P. Hersey, Low natural killer-cell activity and immunoglobulin levels associated with smoking in human subjects, Int. J. Cancer 23 (1979) 603-609.

[8] D.J. Tollerud, J.W. Clark, L.M. Brown, C.Y. Neuland, D.L. Mann, L.K. Pankiw-Trost, W.A. Blattner, R.N. Hoover, Association of cigarette smoking with decreased numbers of circulating natural killer cells, Am. Rev. Respir. Dis. 139 (1989) 194-198.

[9] D. O'Shea, T.J. Cawood, C. O'Farrelly, L. Lynch, Natural killer cells in obesity: impaired function and increased susceptibility to the effects of cigarette smoke, PLoS ONE 5 (2010) e8660.

[10] A. Bendelac, P.B. Savage, L. Teyton, The biology of NKT cells, Annu. Rev. Immunol. 25 (2007) 297-336.

[11] T. Kawano, J. Cui, Y. Koezuka, I. Toura, Y. Kaneko, K. Motoki, H. Ueno, R. Nakagawa, H. Sato, E. Kondo, H. Koseki, M. Taniguchi, CD1d-restricted and TCR-mediated activation of Valpha14 NKT cells by glycosylceramides, Science 278 (1997) 1626-1629.

[12] M. Nieda, A. Nicol, Y. Koezuka, A. Kikuchi, T. Takahashi, H. Nakamura, H. Furukawa, T. Yabe, Y. Ishikawa, K. Tadokoro, T. Juji, Activation of human Valpha24NKT cells by alphaglycosylceramide in a CD1d-restricted and Valpha24TCRmediated manner, Hum. Immunol. 60 (1999) 10-19.

[13] M. Exley, J. Garcia, S.P. Balk, S. Porcelli, Requirements for CD1d recognition by human invariant Valpha24+ CD4-CD8-T cells, J. Exp. Med. 186 (1997) 109-120.

[14] H. Chen, W.E. Paul, Cultured NK1.1+ CD4+ T cells produce large amounts of IL-4 and IFN-gamma upon activation by anti-CD3 or CD1, J. Immunol. 159 (1997) 2240-2249.

[15] J.L. Matsuda, T. Mallevaey, J. Scott-Browne, L. Gapin, CD1drestricted iNKT cells, the 'Swiss-Army knife' of the immune system, Curr. Opin. Immunol. 20 (2008) 358-368.

[16] J. Cui, T. Shin, T. Kawano, H. Sato, E. Kondo, I. Toura, Y. Kaneko, H. Koseki, M. Kanno, M. Taniguchi, Requirement for Valpha14 NKT cells in IL-12-mediated rejection of tumors, Science 278 (1997) 1623-1626.

[17] T. Kawano, J. Cui, Y. Koezuka, I. Toura, Y. Kaneko, H. Sato, E. Kondo, M. Harada, H. Koseki, T. Nakayama, Y. Tanaka, M. Taniguchi, Natural killer-like nonspecific tumor cell lysis mediated by specific ligand-activated Valpha14 NKT cells, Proc. Natl. Acad. Sci. USA 95 (1998) 5690-5693.

[18] S.M. Tahir, O. Cheng, A. Shaulov, Y. Koezuka, G.J. Bubley, S.B. Wilson, S.P. Balk, M.A. Exley, Loss of IFN-gamma production by invariant NK T cells in advanced cancer, J. Immunol. 167 (2001) 4046-4050.

[19] M.V. Dhodapkar, M.D. Geller, D.H. Chang, K. Shimizu, S. Fujii, K.M. Dhodapkar, J. Krasovsky, A reversible defect in natural killer T cell function characterizes the progression of premalignant to malignant multiple myeloma, J. Exp. Med. 197 (2003) 1667-1676.

[20] L. Lynch, D. O'Shea, D.C. Winter, J. Geoghegan, D.G. Doherty, C. O'Farrelly, Invariant NKT cells and CD1d(+) cells amass in human omentum and are depleted in patients with cancer and obesity, Eur. J. Immunol. 39 (2009) 1893-1901.

[21] G. Giaccone, C.J. Punt, Y. Ando, R. Ruijter, N. Nishi, M. Peters, B.M. von Blomberg, R.J. Scheper, H.J. van der Vliet, A.J. van den Eertwegh, M. Roelvink, J. Beijnen, H. Zwierzina, H.M. Pinedo, A phase I study of the natural killer T-cell ligand alpha- galactosylceramide (KRN7000) in patients with solid tumors, Clin. Cancer Res. 8 (2002) 3702-3709.

[22] M. Nieda, M. Okai, A. Tazbirkova, H. Lin, A. Yamaura, K. Ide, R. Abraham, T. Juji, D.J. Macfarlane, A.J. Nicol, Therapeutic activation of Valpha24+Vbeta11+ NKT cells in human subjects results in highly coordinated secondary activation of acquired and innate immunity, Blood 103 (2004) 383-389.

[23] A. Ishikawa, S. Motohashi, E. Ishikawa, H. Fuchida, K. Higashino, M. Otsuji, T. lizasa, T. Nakayama, M. Taniguchi, T. Fujisawa, A phase I study of alpha-galactosylceramide (KRN7000)-pulsed dendritic cells in patients with advanced and recurrent non-small cell lung cancer, Clin. Cancer Res. 11 (2005) 1910-1917.

[24] D.H. Chang, K. Osman, J. Connolly, A. Kukreja, J. Krasovsky, M. Pack, A. Hutchinson, M. Geller, N. Liu, R. Annable, J. Shay, K. Kirchhoff, N. Nishi, Y. Ando, K. Hayashi, H. Hassoun, R.M. Steinman, M.V. Dhodapkar, Sustained expansion of NKT cells and antigen-specific $T$ cells after injection of alphagalactosyl-ceramide loaded mature dendritic cells in cancer patients, J. Exp. Med. 201 (2005) 1503-1517.

[25] M. Exley, S. Porcelli, M. Furman, J. Garcia, S. Balk, CD161 (NKR-P1A) costimulation of CD1d-dependent activation of human $T$ cells expressing invariant $V$ alpha $24 \mathrm{~J}$ alpha $Q T$ cell receptor alpha chains, J. Exp. Med. 188 (1998) 867-876.

[26] T. Kawano, T. Nakayama, N. Kamada, Y. Kaneko, M. Harada, N. Ogura, Y. Akutsu, S. Motohashi, T. lizasa, H. Endo, T. Fujisawa, H. Shinkai, M. Taniguchi, Antitumor cytotoxicity mediated by ligand-activated human $\mathrm{V}$ alpha24 NKT cells, Cancer Res. 59 (1999) 5102-5105.

[27] D. Bernhard, C.W. Huck, T. Jakschitz, G. Pfister, B. Henderson, G.K. Bonn, G. Wick, Development and evaluation of an in vitro model for the analysis of cigarette smoke effects on cultured cells and tissues, J. Pharmacol. Toxicol. Methods 50 (2004) 45-51.

[28] T.J. Cawood, P. Moriarty, C. O'Farrelly, D. O'Shea, Smoking and thyroid-associated ophthalmopathy: a novel explanation of the biological link, J. Clin. Endocrinol. Metab. 92 (2007) 59-64.

[29] M. Kronenberg, Toward an understanding of NKT cell biology: progress and paradoxes, Annu. Rev. Immunol. 23 (2005) 877-900.

[30] J.W. Molling, J.A. Lanigus, J.A. Langendijk, C.R. Leemans, H.J. Bontkes, H.J. van der Vliet, M.E. von Blomberg, R.J. Scheper, A.J. van der Eertwegh, Low levels of circulating Invariant Natural Killer T cells predict poor clinical outcome in patients with Head and Neck Squamous Cell Carcinoma, J. Clin. Oncol. 25 (2007) 862-868.

[31] K.M. Dhodapkar, Harnessing human CD1d restricted T cells for tumour immuntiy: progress and challenges, Front. Biosci. 14 (2010) 796-807.

[32] A. Nicol, M. Nieda, Y. Koezuka, S. Porcelli, K. Suzuki, K. Tadokoro, S. Durrant, T. Juji, Human invariant Valpha24+ natural killer $\mathrm{T}$ cells activated by alpha-galactosylceramide (KRN7000) have cytotoxic anti-tumour activity through mechanisms distinct from $T$ cells and natural killer cells, Immunology 99 (2000) 229-234.

[33] M. Lisbonne, P. Hachem, M.B. Tonanny, J.M. Fourneau, S. Sidobre, M. Kronenberg, P. Van Endert, M. Dy, E. Schneider, M.C. Leite-de-Moraes, In vivo activation of invariant Valpha14 natural killer T cells by alpha-galactosylceramide sequentially induces Fas-dependent and -independent cytotoxicity, Eur. J. Immunol. 34 (2004) 1381-1388. 